\title{
Stigma and Disfigurement: Putting on a Brave Face?
}

This chapter will ask whether acquired (as opposed to congenital) facial disfigurement marked a person as stigmatized in medieval Europe, or whether "abnormal" faces were so commonplace-through disease, infection, birth defects, accidental and deliberate violence-that a disfigured person was effectively invisible. Jacques Le Goff certainly thought so, opining that medieval Europe teemed with the impaired, the blind, the sick and the mutilated. ${ }^{1}$ This may well be true, although the visibility of such groups is undoubtedly exaggerated by their appearance in hagiographic texts: medieval Europe was teeming with would-be saints as well, and the most common context for extended descriptions of people with disabilities is in accounts of miraculous alleviation of their condition. More will be said on "cures" to the face in Chapter 7. This chapter, however, largely bypasses the hagiography to explore examples of different types of disfigurement reported in chronicles and legal material, considering not only the nature of the disfigurement, but also the nature and context of the report itself. Do the writers stigmatize their subjects simply through drawing attention to them, and do they make clear how contemporaries viewed those subjects? Did ubiquity of visible difference in fact mute its potential to cause surprise, shock or disgust? The chapter will ask whether responses to facial disfigurement were conditioned by class or circumstances, and will present some case studies supporting my contention that facial impairment, whether accompanied or not by side effects such as brain injury or loss of senses, was treated differently from maiming of limbs or disease of

P. Skinner, Living with Disfigurement in Early Medieval Europe, DOI 10.1057/978-1-137-54439-1_4 
the body, in that very little could be done either to mitigate its effects or disguise its appearance.

The notion of "stigma" of course immediately brings to mind the distinction made in the social sciences between in-groups and out-groups in any given society. ${ }^{2}$ Medieval historians have long found it useful to consider the work of social scientists, particularly in the fields of anthropology and sociology, to provide insights into less well-documented societies and groups of the early Middle Ages. ${ }^{3}$ Such studies, however, have only recently begun to focus on the margins of medieval society, exploring the socially-excluded, the poor, dissidents and criminality. ${ }^{4}$ I have already suggested that it is difficult to posit disfigured people as a recognizable group in medieval society: certainly they were not conceptualized as such. They therefore seem to have escaped the fate of other groups, highlighted in studies following the seminal work of Bob Moore, but adapting, as well as adopting, his notion of a "persecuting society," such as the blind, lepers, the poor, Jews or even women, all of whom were and still are discussed with little sense of differentiation or recognition that individuals within these groups might be experiencing their perceived "difficulties" in different ways. This is a point made by Edward Wheatley in his ground-breaking study of visually impaired people in medieval Europe: visual impairment not being understood as a range of abilities, the partially-sighted, in particular, faced a dilemma as to whether to reveal their ability to see a little, and thus be accused of faking their "blindness." Wheatley's work is highly relevant to the history of disfigurement, given that a significant number of the visually impaired may have been deliberately blinded, rather than lacking or losing their sight through natural causes. Those who lost their eyes, in particular, would have looked rather different to those whose blinding was through non-invasive methods.

Medieval sources, as we have seen, had no stable term to describe disfigurement, nor were those so afflicted identified as a group. "The disfigured," linguistically at least, do not exist. That is not to say that acquired disfigurement affected only individuals-group disfigurement of defeated enemies is often reported. Thietmar of Merseberg's early eleventh-century history, for example, refers to the shaving and flogging of six men. ${ }^{7}$ Reports of such group mutilation seem to increase sharply from the thirteenth century onwards. Some of the most notorious examples are clustered in accounts of the Albigensian crusade, in which both sides were condemned or excused by chroniclers for tit-for-tat acts of cruelty. In 1210 a local lord, Gerard de Pepieux, abandoned the crusade and mutilated two of 
its knights whom he had captured at Puisserguier by blinding them and cutting off their ears, noses, and upper lips, then sent them back to Simon de Montfort. Later, in retaliation, de Montfort blinded over a hundred defenders of Bram and cut off their noses, leaving one man with a single eye to lead the rest to Cabaret, another fortress resisting the Crusade. The Canso de la Crozada reports another, similar attack by Count Ramon Roger of Foix against a group of German and Frisian crusaders. In 1228, Roger of Wendover reports, Count Raymond of Toulouse captured and mutilated some 2000 French prisoners and sent them back to their homes "shamefully mutilated, a deformed spectacle to their own people." 8 The strong message running through these and earlier sources relating to the wounded faces of warriors, or the legal codes discussed in Chapter 3 dealing with personal injury, is that disfigurement inflicted on another was unsightly or shameful-turpis—and invited ridicule. The sheer impact of a whole group of mutilated bodies in the thirteenth-century cases ensured they were recorded. With the apparent exception of Old Norse society, facial scarring (and, for that matter, congenital deformity) was not seen as a sign of prowess, but instead was read more often as a sign of defeat and disgrace. ${ }^{9}$

Yet the picture we have is made more complex by medieval reflections on the relationship between bodily imperfection and the health of the soul, and the prioritizing of the latter. Writing in the early eleventh century, Thietmar commented:

In me, however, you will see a tiny little man whose jaw and left side of the face are deformed by an ulcer which erupted there and continues to swell. The nose, broken in childhood, gives me a laughable appearance. Of all that I would regret nothing, if only my inner character were bright. ${ }^{10}$

Whilst Thietmar's self-reflection about his appearance is a rarity, the sentiment it expresses is commonplace in medieval texts. A century after Thietmar, Abbot Guibert of Nogent (d.1125) echoed a similar sentiment about physical appearance: "If their internal models are beautiful and good, those who manifest their image, especially if they do not depart from their measure, are beautiful, and hence they are good." ${ }^{11}$ We shall return to the subject of beauty presently.

Medieval authors in fact had a highly sophisticated sense of the difference between the material and the figurative, illustrated most frequently by the differentiation between literal and spiritual sight and blindness. 
The tenth-century Old English version of the Deeds of Andrew and Matthew among the Cannibals, for example, reports that when his eyes were gouged out with a sword, Matthew prayed to God for inner light. ${ }^{12}$ Guibert comments that those who elected him to the abbacy of Nogent were "blind or short-sighted," asking, "what would they have said if they had seen my inner self?" 13 In his account of the martyrdom of the missionary Bruno in 1009, Bruno's companion Wipert recounts how, despite accepting baptism, the Russian king "Nethimer" ordered the execution of Bruno and four of his chaplains. Wipert, the only survivor, then reports matter-of-factly: "he had my eyes taken out [meos oculos eruere fecit]." From that time, he says, he had wandered as a pilgrim of God through many provinces, invoking the aid of the saints to help the Christians, and asking the charitable help of all Christians for the defense of his life and the remedy of their sins. ${ }^{14}$ Wipert hints at the material reality of his situation, but nevertheless sees in his peregrinations the opportunity for others to acquire spiritual rewards by helping him. Such distinctions, despite being didactic in nature, caution against uncritically applying modern assumptions about the misfortune of disfigurement to the medieval cases under review.

So the disfigured were perhaps not a conventionally identified "outgroup" linguistically. But there are different degrees of difference/strangeness, both figurative and literal. Wipert was permanently impaired, but Thietmar's disfigurement placed him on the relatively mild end of the spectrum. Broken noses must have been a common occurrence, after all. More importantly, the major cause of disfigurement to his face, the fistula or ulcer, was a natural phenomenon rather than being inflicted by a third party. But his protest-indeed the fact he raises the issue of his appearance at all-does suggest the potential for others to respond negatively to his facial deformities, and as the number of examples drawn from his text suggests, Thietmar may have had a specific interest in physical difference that has not hitherto attracted much attention from historians.

Disfigured faces were "read" and commented on in medieval texts, it seems, only if their visual impact was obvious and immediate. A late example, but fulfilling a similar didactic function, comes in the thirteenthcentury chronicle of Salimbene. Describing a certain brother Aldevrandus, he says "He had a deformed head in the shape of a helmet of the ancients, with copious hair on his forehead." Although he suffered laughter from the brothers when his turn came to start the antiphon (so all eyes would have been on him?), Aldevrandus's case is used by Salimbene to highlight the lessons of Christ's humility before his persecutors. ${ }^{15}$ We might note 
here the appearance of excessive hair as one element in Aldevrandus's "strange" appearance: Miller comments that this is often the focus for feelings of disgust in modern studies. ${ }^{16}$

Modern studies of facial disfigurement and facial perception focus on the psychological impact on the self and others of "normal" and disrupted appearance. This "first impression" might—or might not—be reinforced by other body language such as speech or gestures, and could be severely disrupted by facial difference. But as sociologists of stigma have pointed out, damaged physical appearance is not only a key factor in shaping the perception of others, but also reinforces the behavior of the stigmatized individual in that s/he may withdraw more and more from potentially "embarrassing" situations. ${ }^{17}$ Was a disfigured person a stranger to themselves, abject in the Kristevan sense that "the skin, a fragile container, no longer guaranteed the integrity of one's 'own and clean self' but ... gave way before the dejection of its contents?" 18 Aldevrandus, in Salimbene's report, was certainly "disturbed and made to blush" by the ridicule of the other brothers. ${ }^{19}$ Did acquired disfigurement throw up issues of recognition and social exclusion among family or community, especially if the damage had occurred away from home, for instance in warfare? And might it lead to a need for physical relocation-spatially "outside" the community - if the disfigurement were read in the wrong way?

Sociologists have extensively explored the concept of stigma since the pioneering work of Erving Goffman in 1963. Goffman's work has also constituted a useful point of reference for medieval historians, although the editors of a volume on stigma published in 1986 commented on historians' rather belated adoption of the concept as an interpretative filter. ${ }^{20} \mathrm{His}$ model of difference, relegating the person to a tainted, discounted member of the community, ${ }^{21}$ however, has not been without its critics. Colin Barnes suggests that applying stigma theory to the physically-impaired, and viewing their impairment as a personal tragedy, not only denies the impaired their own voices, but also "over-emphasizes subjective physiological and cognitive limitations through the professionally-determined authenticity of those determinations." 22 The modern advent of professional care and segregation of the impaired, in other words, has increased and reinforced dependency and isolation. Barnes contrasts this situation with the Middle Ages and early modern periods when the impaired may have been viewed as "abnormal in the purely statistical sense of belonging to a minority group," but were not separated from the mainstream. ${ }^{23}$ The disfigured, of course, might or might not fall into the category of the 
"abnormal." As Sally Crawford and Christina Lee have observed in their discussion of health and sickness, such categories are highly fluid: "it is only when normal health becomes 'abnormal' that it becomes unhealthy, when people move from the normative-in behavior, appearance or emotional or physical well-being-to the boundaries." 24 Yet the concept of stigma can be useful for drilling down into medieval texts that did not, for the most part, explicitly consider the wider implications of a damaged face. A useful study by social psychologist Edward Jones and his colleagues offered "six dimensions of stigma:" concealability; course; disruptiveness; aesthetics; origin and peril. ${ }^{25}$ How useful are these in understanding the medieval experience of damaged appearance?

\section{Concealability: Can the Stigma Be Hidden?}

According to sociologist Shlomo Shoham, visible difference automatically stigmatizes and sets the individual outside the group, as "these individuals and the groups are manifestly different. Their apartness is inherent in their physical attributes." 26 All modern commentators agree that the solution to stigma is to learn to "pass," to conceal or disguise the physical difference sufficiently so as not to be noticed. ${ }^{27}$ In the Middle Ages, the possibilities for concealing facial disfigurement were limited: women, more than men, might be able to cover their heads and faces and look relatively "normal," since a married woman, in particular, was expected to cover her hair (and lawcodes often include penalties for dishonoring women by removing or touching their scarves and hair, as we have already seen) ${ }^{28} \mathrm{~A}$ striking depiction of head and face covering on a woman is incorporated in the Becket windows at Canterbury cathedral: here the mother of the leprous boy is, somewhat ironically, all wrapped up, presumably to prevent contagion, whilst his disease is indicated with a few generic dots on the face and not concealed at all. Whether male lepers went about with their heads and faces partly covered or not is hard to judge: the few and late depictions we have clearly show them concealing themselves. ${ }^{29}$ But having an extensive head wrapping might, in fact, have become an indicator of leprosy: for men the choice of headgear was perhaps more highly charged.

A visible scar, on the other hand, might also have functioned as a memory device, recalling the circumstances in which it was acquired. For example the Flemish count William, involved in a violent confrontation at Avesnes (c.1147), received a sword wound on the head, whilst climbing down a ladder from the church tower which left him scarred for life. ${ }^{30}$ 
The almost contemporary Gerald of Wales develops this idea further, utilizing a scar acquired in battle as a device to discuss legitimacy: the knight Erchembald, he reports, bore exactly the same scar at his birth as his father had acquired in battle when nicked on the top lip by a spear, thereby saving his mother from suspicion of adultery. ${ }^{31}$

Three cases of missing ears demonstrate that the visibility of, and level of stigma attached to, a mutilated person could very much vary with the circumstances in which the mutilation had been suffered. The sixthcentury history of Bishop Gregory of Tours provides the first example, a character assassination of Count Leudast of Tours, whom he portrays as the son of a slave. Sent to work in the royal kitchens as a child, Leudast ran away, and was punished by having one of his ears slit. "As there was no possibility of concealing this mark on his body," the young Leudast fled to Queen Marcovefa, who took pity on him and gave him a job in her stables. From here on, Gregory relates, Leudast essentially worked his way up to his comital position, and was appointed as a punishment to the people of Tours for their immense sins. ${ }^{32}$ It is easy to dismiss Gregory's jaundiced view of the count as nothing more than a series of rhetorical flourishes-assigning low birth to a prominent figure was, throughout this period, a well-known tool for attacking them. ${ }^{33}$ But clearly Leudast's ear was "wrong," and by drawing attention to it Gregory was able to construct the image of a man without much honor, in his eyes. Similar processes are at work in a case reported by the ninth-century Byzantine chronicler Theophanes. He reproduces a story relating to the fifth-century patrician Illos, whose right ear was cut off in an assassination attempt:

When he was cured of the wound, he used to wear a cap. He asked the emperor to send him to the East so that he could enjoy a change of air because he was weak from the wound..$^{34}$

This story is told as a prelude to a later rebellion-from the very eastern provinces to which Illos had retired-by the same man. It seems pretty clear that Illos is being set up by Theophanes as in some way dishonored by his wound (possibly by the circumstances in which it was acquired-he clearly was not popular), hinting that his withdrawal was not for health reasons but to render his lack of ear, which he also tried to hide with a cap, even less visible. Examining Byzantine iconography, it is in fact quite difficult to find evidence of male headgear except in the case of imperial crowns and head-dresses, so in highlighting the cap Theophanes may well 
have been drawing further attention to Illos's misfortune and status as "outside" the norms of the court once he withdrew.

Contrast these cases, in which the missing or damaged ear functioned as a negative element, with Thietmar of Merseberg's account of Bishop Michael of Regensburg (d. 972). He comments that Michael had lost an ear in battle, but "his mutilation was not to his shame but more to his honor." 35 The bishop's lack of an ear would have been apparent, but since he had acquired the injury in battle against the pagan Hungarians, the possible shame inherent in the injury was countered by the heroic way in which it had been acquired. In fact, Irina Metzler makes the important point that if a mutilation occurred after a priest had entered holy orders, he was permitted to maintain his position. Hence, Thietmar took the time to tell Michael's story. ${ }^{36}$ For Leudast, Illos and Michael the visible injury was the same, but the stigma attached to it by those reporting the cases differed greatly, according to the back-story of its acquisition. (And the story mattered: Theophanes features an earlier, mutilated priest in the figure of Maximus, who became patriarch of Jerusalem in the early fourth century despite his lack of one eye. Theophanes attributes this to Maximus having "endured many tortures ( $\pi 0 \lambda \lambda \alpha \alpha_{\varsigma} \beta \alpha \sigma \alpha \dot{\nu} 0 v \varsigma v \pi 0 \sigma \tau \alpha \varsigma$ ), implying that he had been caught up in the last great persecutions of Christians before toleration was decreed by Constantine, and thus, like Michael, could be presented as a hero for his faith. $)^{37}$ Was Thietmar in fact inclined to be more sympathetic to those who, like him, looked different? Or was his account shaped purely by his terms of reference, in this case the need to defend a deformed bishop from the accusation that his loss of an ear compromised his suitability to serve as a priest (and, by extension, reinforce his own legitimacy as a bishop despite his deformity)?

There is another dimension to the loss of ears, since the most famous case, which all of our protagonists would have been well aware of, was the attack by Simon Peter on Malchus, servant of the high priest, as Christ was arrested in the Garden of Gethsemane (John, 18:10). The Biblical account does not say whether this is whom Simon Peter was aiming at, but he succeeded in cutting off Malchus's ear with his sword. John's account shows Christ rebuking Peter for his action, and later artists would use this scene to show him miraculously re-attaching the missing ear. Either way, the episode with Malchus is adopted by medieval authors such as Orderic Vitalis to express violence, significantly in defense of the pope in $1106 .{ }^{38}$

Of course, what links all these cases is the fact that most of the men concerned were all expected to be highly visible in public - whether attending 
court as elite men (Illos at the imperial court, for example), or officiating in public offices (Patriarch Maximus, Bishops Michael and Thietmar). In early Irish laws, the Bretha Déin Chécht took account of the long-term effects of disfigurement when it awarded the victim one cumal (the price of a slave-girl) for every occasion on which he had to attend the public assembly with his visible scars. ${ }^{39}$ The issue of visibility recurs in many other early lawcodes, including the Welsh laws of Hywel Dda as transmitted in the Book of Blegywryd..$^{40}$ As we have already explored in Chapter 2, the requirement to live a life in public, particularly for men of high status, meant that their appearance mattered.

\section{Course: Could the Stigmatizing Condition Be Changed Over Time?}

There are two aspects to the question of change over time: the possibility of changing one's physical appearance, and the possibility of changing the meaning of, and response to, the disfigurement. For medieval people, facial disfigurement was not easy to remedy or improve. The loss of ears, for instance, was permanent, and probably brought with it some auditory impairment as well. In the case of wounds acquired in warfare, however, the care received at the time might radically affect how bad the subsequent disfigurement might be: the work of Piers Mitchell has demonstrated that care on the battlefield, or immediately afterwards, was available to crusaders in the Holy Land.$^{41}$ Depending on time and place, therefore, there was a slight possibility of modifying, if not totally changing, the disfiguring condition.

Medieval case studies of such care are still very rare, but the potential difference it could make to subsequent appearance has been startlingly illustrated by an example drawn from antiquity: the reconstruction of King Philip of Macedon's face (based on his archaeological remains) by John Prag and Richard Neave and their team at Manchester. Philip had been hit diagonally across his face by an arrow shot from above, shattering his eye socket and depriving him of an eye. The reconstruction team, aided by make-up artists from the local television station, was able to produce a highly realistic wax effigy, complete with the devastating wound. However, just as this model was being completed it was learnt that Philip, as reported in Pliny's Natural History, had in fact received care from one of the most skilled surgeons of his era (the late fourth century BC), Kritoboulos, and so the team also reconstructed the face to reflect the 
possibility of this intervention. In place of a raw, open chasm in his face there is a neat line indicating suturing, complete with closed eye socket. These full-color "before" and "after" images, however, were thought too disturbing to go on display, and a bronze rendition was eventually made for Manchester Museum. ${ }^{42}$

Whilst Philip's may be a special case, it is important not to assume that wounded medieval warriors lacked any kind of care. Arrow wounds were ubiquitous, reflecting the fact that the face was the most vulnerable part of a warrior's body. ${ }^{43}$ An illustration from Peter of Eboli's Liber ad Honorem Augusti, produced at the end of the twelfth century, suggests that immediate care was sometimes available. Depicting in one scene Count Richard of Acerra's face being horizontally pierced by an arrow at the siege of Naples (1191), the narrative then continues with another illustration depicting Richard being attended to by a man labeled "medicus" and two female assistants. ${ }^{44}$ We know that Richard survived his wound (only to be executed for treachery some years afterwards): the detailed pictures suggest that the arrow hit Richard's cheeks, narrowly missing his jawbone, but he must nevertheless have had two major scars on his face thereafter. Arrow wounds to the head and face, in fact, are one of the most common disfiguring (but often also fatal) injuries reported by chroniclers. ${ }^{45}$

The only evidence we have of potential change in the form of a facial prosthesis in the early Middle Ages, however, is the highly-suspect western account by the ninth-century author Agnellus of Ravenna of the Byzantine Emperor Justinian II's golden nose and ears. ${ }^{46}$ The basic problem with Agnellus's account, besides its geographical and chronological distance from the events it describes, is that it is our only evidence for the prosthetic nose and ears. Byzantine sources in the east report the mutilation, but the idea of a golden nose may well derive from Agnellus's proximity to the richly decorated mosaic portrayals of Justinian's earlier namesake still extant at Ravenna. A recent report of a gold solidus of Justinian II, on which both the emperor's and Christ's faces have been disfigured by a blow to the nose, opens the intriguing possibility that the power of images was understood and in this case used to undermine the emperor further. ${ }^{47}$

For most, however, a facial disfigurement was unlikely to improve, and would become worse with age as the facial muscles lost their tension. As Irina Metzler has rightly highlighted, referring to acquired impairment, the stage in a person's life when disfigurement occurred, as well as its severity, could also have a greater or lesser effect on their future. ${ }^{48}$ 


\section{Disruptiveness: Does the Stigmatizing Condition Disturb Social InTERActions?}

Here, the circumstances in which the disfigurement had been acquired had direct implications. Medieval life was played out far more publicly and communally than life today. The study of medieval fama, the common knowledge within a community spread by gossip and rumor, has revealed how important gaining and maintaining a reputation could be. ${ }^{49}$ We have also already seen how quickly news of misfortune could spread, as illustrated by Thietmar's account of the pirate attacks of 994 and capture of hostages. ${ }^{50}$ If a person had a terrible accident or disease that left them scarred, the knowledge of that event would spread and then remain in the memory of her/his family, friends and neighbors, and whilst the victim remained in the locality, that knowledge might have formed a protection of sorts. ${ }^{51}$ The recorded use of nicknames indicating disability or facial difference, whilst apparently highlighting a person's misfortune, might actually indicate that they were still accepted as part of the community. ${ }^{52}$ Conversely, mutilation inflicted as a penalty, or suffering mutilation at the hands of the enemy in a military defeat, would also be remembered, and whether the victim's social interactions continued in the same vein as before would depend very much upon the opinion of the community regarding their crime or the damage to their honor inflicted by defeat. ${ }^{53}$ This was contingent upon the circumstances in which the disfigurement was acquired, and a further distinction affecting the reception of the injury might have been whether it was accidental or deliberate. Our sources, however, are almost entirely concerned with the latter, and in some cases the disfigurement (or threat of disfigurement) follows on from illegitimate acts, that is, the person has already jeopardized their communal ties by their behavior, whether treasonous, criminal or adulterous. We have already met, and will continue to meet, guilty men and women who were disfigured and either paraded as a lesson to others or shut away and deprived of their normal social interactions. Here, the disfigurement simply marks that person out, and links the stigma to the assumed deviance of the person concerned.

Even rare cases of reports of "accidental" facial injury turn out to be loaded with significance for future social interactions. An apparently trivial aside in the Anglo-Saxon "Fonthill Letter" turns out to be anything but. The subject of the letter, dated between 899 and 924, is Helmstan, whose repeated thefts of property caused confiscations of land to which he does 
not appear to have had full title. The author of the letter is essentially defending his own right to the estates at issue. In passing, however, the writer recounts that Helmstan had stolen some oxen and driven them to Cricklade where he was apprehended by a man who recognized the cattle. "When he fled, a bramble scratched him in the face and when he wished to deny it, that was brought as evidence against him [my emphasis]." 54 Without suggesting that Helmstan was seriously or permanently disfigured by the bramble scratches, they were clearly sufficiently visible and serious to function as proof of his flight; moreover, in marking him out as a thief they had generated a memory of his actions that was now being rehearsed again and committed to writing even after his face hadpresumably-healed up. Helmstan may or may not have been scarred or disfigured by the theft, but his reputation surely was.

As a thief, Helmstan was fortunate to escape further physical punishment. Other crimes, such as treason, attracted more severe penalties: the would-be assassins of King Childebert II of Francia, as we have seen, were deprived of their ears and noses then "let out as a subject of ridicule," according to Gregory of Tours. ${ }^{55}$ Wheatley comments that blinded criminals "would have been shunned as long as they remained in locations where their criminal past was known." 56 This brings to mind the comment of sociologists Mark Stafford and Richard Scott, who point out that the process of stigma depends very much on the "power weight" of the person stigmatizing: ${ }^{57}$ these mutilations - and their permanent, exclusionary effect on the victims' lives - were legitimized by the fact that they were inflicted by royal or religious authorities. As we have seen in Chapter 3, however, such acts could only be justified, in our authors' accounts, in very specific circumstances. Inflicting such injuries without the authority to do so was a sign of another type of social disruption.

\section{Aesthetics: Is the Condition Viewed as Repellent OR UGLY?}

This question raises interesting issues as to what was considered beautiful or ugly in the early Middle Ages. As Umberto Eco has pointed out, beauty can be contemplated dispassionately, the perfection of form being appreciated but not necessarily desired. Ugliness, by contrast, frequently evokes an emotive response, and this might be one of disgust, if the ugliness was caused by a severe disfigurement. We have already met William Ian Miller's framing of the disgust response, but the notion of "disgust" 
is still also employed in modern studies of disfigurement perception. ${ }^{58}$ Given that early medieval artists were not concerned to produce a faithful depiction of facial features (as will be explored in Chapter 6), we are reliant on medieval authors describing beauty for us, rather than visual evidence. Texts were no less generic, of course, but they do reveal for us something of the ideals of physical appearance. Anna Komnena, for example, reflects on the Norman leader Robert Guiscard's ruddy complexion, fair hair and broad shoulders, further noting that "In a well-built man, one looks for breadth here and slimness there; in him all was admirably well-proportioned and elegant." 59 Anna also provides a description of her mother as a young woman: "her body absolutely symmetrical...her face... slightly oval in shape. There were rose blossoms in her cheeks...Her light blue eyes were both gay and stern... For the most part her lips were closed and when thus silent she resembled a veritable statue of Beauty, a breathing monument of Harmony." 60 In Anna, proportion and symmetry are at the heart of her ideals, reflecting her classical education, and as we have seen, symmetry lies at the heart of human cognitive processing of faces. ${ }^{61}$ Abbot Guibert of Nogent (d. 1121) also presents us with an idealized portrait of his own mother's beauty, but uses it to reflect on moral quality: however fleeting physical beauty might be, he opines, it symbolizes goodness. Yet it could only fulfill that function when allied with chastity, as in his mother's case.

The destruction of beauty, then, could be read as a sign of moral failure-Guibert suggests that "a blemished exterior is rightly a matter for sorrow." ${ }^{2}$ As we have seen, several sets of laws threatened women (and some men, in the Byzantine laws) who committed sexual misdemeanors such as adultery, prostitution or pimping, with the loss or mutilation of their noses. ${ }^{63}$ Mutilation prevailed in the laws of mid-thirteenth-century Cyprus, themselves based on earlier provisions in the Kingdom of Jerusalem (and not only for sexual transgression), but in the absence of earlier evidence it is unclear whether such penalties arrived with the crusaders. ${ }^{64}$ Furthermore, just as the laws threatened mutilation after the sexual acts (and implied in doing so that the offenders would be rendered repellent to future sexual partners), so hagiographers presented self-disfigurement as an effective deterrent (for female saints, at least) to unwanted sexual attention. Thus the ninth-century abbess Ebba of Coldingham and her nuns are famously reported as self-mutilating in order to avoid rape by Viking attackers in England. ${ }^{65}$ The self-humiliation that such a mutilation would cause was taken up by hagiographers of the twelfth and thirteenth 
centuries, who revived this early medieval motif in the vitae of three holy women, Oda of Brabant (d. 1158), who succeeded in cutting her nose; St Margaret of Hungary (d. 1270), who threatened to do so in order to avoid unwanted marriage, but also as a deterrent to the invading Mongols - an echo of the earlier example of fear of rape by pagans - and St Margaret of Cortona (d.1297), whose regret at her earlier life of promiscuity included a plea to be allowed to destroy her (notably) beautiful face, a request turned down by her confessor. ${ }^{66}$ What is striking here is the fact that whilst the holy women all wanted to self-mutilate, only one (Oda) succeeded, and she was never in fact canonized, suggesting at least some ambivalence regarding her "heroic" gesture. In essence, by taking matters into her own hands she stigmatized herself in the eyes of a Church that valued and promoted obedience and abhorred the shedding of blood. ${ }^{67}$

Extreme examples of ugliness in fictional works can also offer further insight into ideals of good looks. Salimbene's tale of brother Aldevrandus, mentioned earlier, simply repeats tropes found in other tales of hirsute people, such as those in early Irish myths. These often combine disfigurement with other conditions to describe unfortunate individuals, but their descriptions seem to verge on the non-human in their bestial qualities: "if his snout were thrown against a branch it would stick there... if her snout were thrown against a branch, the branch would support it, while her lower lip extended to her knee." ${ }^{68}$ The fantasy of facial change is also embedded in stories such as Marie de France's Bisclavret: the treacherous wife, deprived of her nose by her angry, werewolf husband, subsequently gives birth to similarly disfigured, noseless daughters, a permanent reminder of her betrayal. ${ }^{69}$ Guibert of Nogent, too, equates ugliness with evil in his portrayal of Thiégaud, servant of Enguerrand of Coucy, responsible for collecting bridge tolls. Abusing this position, Thiégaud would rob and even murder travellers: "the unrestrained wickedness of his heart," Guibert comments, "was displayed in his hideous face."

\section{Origin: Can the Stigmatizing Condition Be Blamed on the Person Himself or Herself?}

This element of the discussion engages with one of the enduring tensions surrounding medieval disease and impairment, whether it was attributable to some flaw of character or behavior in the person her/himself (thus interpreted as a punishment of sorts), or whether external forces working through the body's humors resulted in the condition. Acquired 
disfigurement falls between these two stools, in that it was usually the work of a third party rather than God, yet could sometimes be attributed to the behavior of the person disfigured (Bisclavret's wife's daughters carried the sign of their mother's transgression, for example.) Helmstan's guilt, as we have seen, was writ large in the bramble scratches on his face. As Sander Gilman comments, sight has the power to create a moral indictment. ${ }^{71}$ The framework of assigning blame for disfigurement has of course a particularly rich applicability for analyzing medieval texts, since many of the stories considered so far were clearly included to impart moral lessons to the reader. In some instances, the same incident was recorded by different authors, such as the pirate attacks in Thietmar and Adam of Bremen, but opinions might vary as to what the reader was supposed to conclude from the inclusion of such stories.

A case in point is the tale of Young Charles, the son of the Carolingian Emperor Charles the Bald, severely wounded in the face with a sword during a bout of play-fighting. The Annals of St Bertin record for the year 864:

Young Charles ... while he only meant to enjoy some horseplay with other young men of his own age ... by the work of the devil was struck in the head with a sword by a youth named Albuin. The blow penetrated almost as far as the brain, reaching from his left temple to his right cheekbone and jaw... ${ }^{72}$

Here, the major injury Charles received was presented as accidental-there was no hint in the source that his assailant intended to injure him (and thus no reference in the annals to compensation by, or punishment of, Albuin being demanded). Following from this, secondly, Charles appears not to have been dishonored by his injury-in fact, he continued in the honorable position as sub-king of Aquitaine for the two remaining years of his life. The annals do report, however, that he suffered epileptic fits thereafter, and it is doubtful whether he escaped other impairments given the severity of the injury. ${ }^{73}$ Yet the chroniclers disagreed on the circumstances of the injury: whilst the St Bertin annals present it as accidental and remain silent on the issue of honor, Ado of Vienne (d. 870) reports that Charles was "molestatus et dehonestatus" by his injury. ${ }^{74}$ Moreover, Regino of Prum (d. 915) tells a rather different story of the incident, saying that Charles provoked Albuin's attack "out of the levity of youth" and that his assailant struck him on the head with his sword, leaving him half-dead with a "deformed face [vultu deformatus]." 75 For Regino, therefore, the 
disfigurement was Charles's own fault, a condition that his irresponsible behavior had brought upon himself.

Thietmar also recounts an example hinting at moral opprobrium: his nephew Henry's blinding of a soldier. As we have seen, the soldier is described as "distinguished but over proud (egregium set nimis superbum)." Moreover, Henry is also described as having suffered (unspecified) injuries which, as we now know, might have consisted of either physical or verbal abuse. Despite the fact that Henry was exiled for his extreme response, Thietmar is careful to point out that he and the king were soon reconciled. It is hard to avoid the conclusion that he is doing everything he can to suggest to the reader that, in some way, the unnamed soldier was partly responsible for his own fate through his pride and his provocation, and Henry's guilt is further ameliorated by Thietmar's addition that his exile ended and he was eventually reconciled with the king. ${ }^{76}$ A detail in Peter of Eboli's account of Richard of Acerra also hints that the count's non-fatal but marking arrow injury was his own fault, for climbing up to the walls of Naples he "makes a mockery of men whose skill lay in the bow" below and gets his just reward: "The arrow flashed as it shot through the middle of his cheek." 77

\section{Peril: Does the Stigma Represent Danger to Other INDIVIDUALS OR THE COMMUNITY?}

Facial deformity might be taken as a signal of disease, specifically referring to leprosy, but the isolation of lepers does not appear to have been as straightforwardly stigmatizing as might be assumed. Disfigurement, arguably, did not in and of itself represent peril to the community, but if the message of mutilated noses and ears was of criminality and deviance, then a person might find himself or herself treated as a threat. Still more worrying would be the arrival of the disfigured stranger in a town or village community, but their unfamiliarity, rather than their facial difference, would mark them out straightaway. ${ }^{78}$ It is hard, therefore, to see facial disfigurement as an actual sign of "peril" in medieval society. Moreover, on occasion facial modification is presented as an (ill-conceived) attempt at self-protection: Theophanes reports the story of a group of Turks, captured and sent to Constantinople in $588 / 9$, who had "the symbol of the cross tattooed [literally 'embroidered'

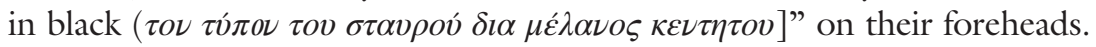
When asked why they had this sign, they responded that they had been advised by Christians to get the tattoos to protect themselves from plague. ${ }^{79}$

Yet, discussions of stigma often include the notion of taboo: the stigmatized individual carrying with them so much ill fortune that their fate 
can have wider repercussions. One specific society, early Ireland, seems to have had a much stronger sense of the potential threat posed by a damaged face, especially if it was the face of a leader. Fergus Kelly points out that the log n'enech or honor price in Irish laws (a concept mirrored in most early medieval lawcodes-wergild in England and on the continent, sarbaed and wynebwerth in Wales - to express the status of the person and the compensation to be paid in the event of injuring or killing them) had the literal meaning of the "price of her/his face." An Irish king's body, however, needed to be perfect-any mutilation or injury was a taboo or geis, requiring his removal from power and threatening the well-being of the community if he stayed. Kelly cites the case of Congal Cáech, ruler of Ulster and Tara, who was blinded in one eye by a bee sting and who was thus "put from the kingship of Tara" (though not Ulster, which he ruled until 637 - such is the fluidity of taboos). ${ }^{80}$

\section{Messages in a Marked Face}

It has proven a useful exercise to combine six modern categories of stigma with the evidence of medieval texts, but this rather skirts round the original question as to whether the medieval disfigured were stigmatized in their communities. So let us return to one of those categories, disruptiveness, and expand a little more on whether disfigurement damaged or broke an individual's ties with her or his community. A well-known law of King Cnut seems to suggest, in fact, that disfigurement might be the expression of social marginalization. In clause 30 of his secular laws it is stated:

30. And if any man is so regarded with suspicion by the hundred and so frequently accused, and three men together then accuse him, there is then to be nothing for it but that he is to go to the three-fold ordeal...

$30.3 \mathrm{~b}$ And if he is then convicted, on the first occasion he is to pay two-fold compensation...

30.4 And on the second occasion there is to be no other compensation...but that his hands, or feet, or both, in proportion to the deed, are to be cut off.

30.5 And if, however, he has committed still further crimes, his eyes are to be put out and his nose and ears and upper lip cut off, or his scalp removed, whichever of these is then decreed by those with whom the decision rests; thus one can punish and at the same time preserve the soul [my emphasis]. ${ }^{81}$

Now whilst this series of increasingly severe penalties relies upon serious recidivism to reach the stage of selective or wholesale disfigurement (slaves, it might be noted, were branded on their first offence), 
nevertheless the path toward becoming disfigured starts here with the man being "regarded with suspicion." 82 So again we see reputation as a key element - and disfigurement as the sign that there had been a real social breakdown. Although the king was keen to "preserve the soul," death might well have been preferable to the punishment meted out here.

Another key question is how to quantify disfigured people: were maimed and damaged faces so commonplace as to resist stigmatization? In fact, reports of disfigurement in narrative sources, whilst surprisingly frequent, seem to counter Le Goff's view, emphasizing more often than not the exceptionality, and often the illegitimacy of facial mutilation. They also share a generic language to express this. In many examples, in fact, extending from the reports of Gregory of Tours to Orderic Vitalis's portrayals of Robert of Bellême and William Talvas, ${ }^{83}$ to the chronicles of thirteenthcentury conflicts, facial disfigurement functions as an act of retaliation or extreme anger (furor), and is used to indict the lack of control (demens, literally madness) or cruelty on the part of the person mutilating. ${ }^{84} \mathrm{~A}$ classic example is Amatus of Montecassino's extended description of Prince Gisulf II of Salerno's cruelty to his Amalfitan hostages in the eleventh century: "Besides being deprived of a limb, or sometimes half a limb, they lost an eye, a hand or a foot. If someone could not ransom himself, they would gouge out both his eyes." ${ }^{85}$ Slightly later, Emperor Frederick II's treatment of Genoese archers, "manu et oculo mutilati" after his capture of Milan in 1245, would just be another atrocity of war, had not the report by Bartholomew Scriba also included the detail that the mutilated men received a pension when they returned to their home city. ${ }^{86}$ This underlines the contingency of mutilation and disfigurement: to Frederick, the Genoese were traitors, but to their co-citizens (and Bartholomew) they were heroes, worthy of economic support now that they were deprived of their livelihood. As in so many cases, however, this report is exceptional: it does not permit us to claim that all war-wounded men were treated with such sympathy and practical help.

Taken together with the numerous and extraordinarily detailed clauses in almost every early medieval lawcode condemning injuries to head, face and body parts (see Chapter 3 and Appendix 2), such reports caution against the assumption that a person with a disfiguring injury would automatically be stigmatized, still less evoke disgust in the viewer. It does seem, however, that individuals with acquired disfigurements had to have a special story in order to be recorded in narrative and other sources-the 
account of Helmstan's scratched face is a case in point. Whether these exceptional cases prove Le Goff's point about the ubiquity of disfigurement and disease among the larger population is a moot point. It is also worth noting that those whose stories were recorded in the chronicle evidence cited in this chapter were exclusively drawn from the social elite. Arguably, these men (I will revisit the women in Chapter 5, when the gendering of disfigurement will be explored in greater detail) were secure enough in their status to be able to override any doubts about the facial damage they suffered or were willing to suffer. We cannot discount the possibility that the writing-up of their cases was itself a carefully managed operation-it is striking that later accounts of Young Charles's injury, for example, take a progressively less sympathetic line. ${ }^{87}$

At the same time, the strong sense that the earthly body was less important than inner cleanliness, expressed by Thietmar, seems to have given license to reporters to explore facial disfigurement in more imaginative ways. Such a case is the extended treatment, in Orderic Vitalis's Ecclesiastical History, of Walchelin the priest's vision of the walking dead, including being attacked and dragged along the ground by an evil knight with burning hands. Fifteen years later, he recounted his tale to Orderic, who believed his informant on the basis that "I saw the scar on his face caused by the touch of the terrible knight." 88 Clearly Walchelin had a visibly-scarred face, possibly from a rather more mundane accident with fire, but his story, it seems, was designed to deflect the attention of viewers, providing a supernatural explanation worthy of recording and gaining him belated attention. If Walchelin was able to turn his scar into something positive, it is striking too that whilst political maiming, as seen in the case of Justinian II, was intended to disbar him from rule, he was able to overcome his stigmatizing condition through sheer determination and the acquisition of allies from outside the court (if not, more's the pity, through sporting a matching set of gold nose and ears).

Returning then to the questions with which this chapter opened, it does not appear that early medieval authors automatically wrote stigma into their accounts of people with disfigurements. Class does seem to have been a major factor both in the generation of records and in how they were viewed. The damaged faces of the elite might provoke questions, and on occasion were attributed negatively to the fault of the disfigured person. The early medieval laws attributed more compensation to the wellborn victim of disfigurement than the peasant or the unfree, recognizing 
that shame - or, to use the sources' own term, ridicule - might result from attending public events with a mutilated face. Much more frequently, however, disfigurement as a result of interpersonal violence indicted the perpetrator in the narrative texts, rather than the victim: if disgust was present as a response to the victim, it is not manifested in the written accounts, and this absence is telling. And whilst there might have been a clear, biblical framework for assessing the parameters of acceptable violence, there is no clear or uniform scheme framing reports of disfigurement. An exception to this statement may have been a heightened awareness, among clerical writers, of the Levitical disbarring of priests with deformities, but this does not, as a rule, seem to have prevented such men from serving the Church, if Thietmar's text or Orderic's story of Walchelin are any indication. Indeed, it is possible to suggest, in light of several of the stories discussed in this and the previous chapter, that the Christian values underpinning most of our authors' accounts provided space for those with disfigurements, albeit space conditioned by pity for the victim's condition, or the opportunity to draw moral lessons from that condition or the behavior of the person who had inflicted their terrible injuries. Pope Leo's shining scar, discussed above, bore witness to the miracle of his sight being returned to him, Wipert turned the adversity of his blinding to a triumph of patient humility and a tool for others' salvation, and Walchelin won an ally in Orderic by presenting his burns in the entirely orthodox language of a vision. Unfortunately, Thietmar does not elaborate on why Duke Henry of Bavaria ordered the blinding of the archbishop of Salzburg and the castration of the patriarch of Aquileia (note again the contiguity of the two mutilations), simply branding this act "impious," but his resultant land grab for his vassals provides us with a clue. ${ }^{89}$

Disfigurement in and of itself was not sufficient to generate a written record, however, nor did it alone generate social marginalization. The Irish evidence highlights the other main issue raised at the start of the chapter: whether geographical region conditioned written or recorded responses to disfigured people. It does appear there was some distinction between different parts of Europe. It has been suggested that Old Norse society valued, rather than abhorred, the battle-scarred face; Celtic societies, on the other hand, seem to have had a heightened sensitivity to facial difference, and linked honor linguistically to the face and nose, as evidenced by Welsh and Irish laws, and myths from the latter region. Between these two poles lay the vast majority of cases, whose presentation and interpretation 
in written narratives was heavily contingent upon the circumstances of the acquisition of the disfigurement, and do not offer a universalizing, stigmatized view of disfigured people.

\section{Notes}

1. J. Le Goff, Medieval Civilization, 400-1500, tr. J. Barrow (Oxford: Blackwell, 1988), 240.

2. An idea made popular by Henri Tajfel: see his "Intergroup relations, social myths and social justice in social psychology," in The Social Dimension, ed. H. Tajfel, II (Cambridge: Cambridge University Press, 1984), 695-716.

3. Starting with J. M. Wallace-Hadrill's work on the Franks, The LongHaired Kings and other Studies on Frankish History (New York: Barnes and Noble, 1962), utilizing classic anthropological studies such as Marcel Mauss, The Gift: the Form and Reason for Exchange in Archaic Societies (London: Cohen and West, 1954) and Max Gluckmann, "The peace in the feud," Past and Present, 8 (1955): 1-14; The Settlement of Disputes in Early Medieval Europe, ed. Wendy Davies and Paul Fouracre (Cambridge: Cambridge University Press, 1986); Property and Power in the Early Middle Ages, ed. Wendy Davies and Paul Fouracre (Cambridge: Cambridge University Press, 1995); The Languages of Gift in the Early Middle Ages, ed. Wendy Davies and Paul Fouracre (Cambridge: Cambridge University Press, 2014).

4. E.g. Bronislaw Geremek, The Margins of Society in Late Medieval Paris (Cambridge: Cambridge University Press, 1987); Michael Goodich, Other Middle Ages: Witnesses at the Margins of Medieval Society (Philadelphia: University of Pennsylvania Press, 1998); Monks and Nuns, Saints and Outcasts, ed. Lester K. Little, Sharon H. Farmer and Barbara H. Rosenwein (Ithaca, NY: Cornell University Press, 2000); Andrew McCall, The Medieval Underworld (Stroud: Sutton, 2004).

5. R. I. Moore, The Formation of a Persecuting Society (Oxford: Blackwell, 1987, 2nd ed. 2007).

6. Edward Wheatley, Stumbling Blocks before the Blind: Medieval Constructions of a Disability (Ann Arbor: University of Michigan Press, 2010). 
7. Thietmar, VIII.22: Namque homines sex flagellati ac depilati cum edificiis turpiter mutilatis approbant, qualiter tanti seniores ab aliis precaveri debeant. Note the use of "shamefully" here.

8. Puisserguier: The History of the Albigensian Crusade: Peter of LesVaux-de-Cernay's Historia Albigensis, tr. W. A. Sibly and M. D. Sibly (Woodbridge: Boydell, 1998), I.142. I am grateful to Daniel Power for reminding me of this notorious case, on which see also Megan Cassidy-Welch, "Images of blood in the Historia Albigensis of Peter des Vaux-de-Cernay," Journal of Religious History, 35 (2011): 478-491, especially 487. Karen Sullivan, "The good, the bad and the beautiful: violence in the Canso de la Crozada," in Violence and the Writing of History in the Medieval Francophone World, ed. Noah D. Guynn and Zrinka Stahuljak (Cambridge: D. S. Brewer, 2013), 99-114; Rogeri de Wendover, Chronica, ed. H. Coxe (London: Sumptis Societatis, 1842), IV.170: sic turpiter mutilatos ad propria remittens deforme spectaculum Francigenis...

9. Patricia Skinner, "Visible prowess? Reading men's head and face wounds in early medieval Europe to 1000CE," in Wounds and Wound Repair in Medieval Culture, ed. Larissa Tracy and Kelly de Vries (Leiden: Brill, 2015), 81-101. The ambiguity of attitudes toward disfigurement in the saga literature is explored by Lois Bragg, "Disfigurement, disability and dis-integration in Sturlunga saga," alvissimál, 4 (1994[1995]): 15-32.

10. Thietmar, IV.75 (51): ...videbis in me parvum homuncionem, maxillum deformem leva et latere eodem, quia hinc olim erupit semper turgescens fistula. Nasus in puericia fractus de me ridiculum facit. Idque totum nil questus essem, si interius aliquid splendescerem. English translation in Ottonian Germany: the Chronicon of Thietmar of Merseburg, tr. David A. Warner (Manchester: Manchester University Press, 2001), 203-4.

11. Self and Society in Medieval France: The Memoirs of Abbot Guibert of Nogent, ed. and tr. John Benton (New York: Harper and Row, 1970), I.2, 39.

12. Cited in Paul Beekman Taylor, "Wounds, wit and words," in Fleshly Things and Spiritual Matters: Studies on the Medieval Body in Honour of Margaret Bridges, ed. Nicole Nyffenegger and Katrin Rupp (Newcastle: Cambridge Scholars Press, 2011), 125-139, at 126.

13. Self and Society, I.19, 100. 
14. Ex illo tempore pro Deo peregrinando circuivi plurimas provincias, invocans sanctos sanctasque in christianorum auxilia...Omnium christianorum in karitate Dei deposco auxilium, quod mee vite fiat patrocinium, vestrorum peccatorum eternum remedium: Wipert's account is reproduced in the preliminary matter to the Vita S. Adalberti Episcopi, in MGH SS, IV, ed. G. H. Pertz (Hannover: Hahn, 1841), 579-580.

15. Habebat enim caput deforme et factum ad modum gálee antiquorum, et pilos multos in fronte: Chronica Fratris Salimbene Ordinis Minorum. Liber de Praelatio, ed. O. Holder-Egger, in MGH SS, XXXII, ed. G. H. Pertz (Hannover: Hahn, 1913), 137.

16. William Ian Miller, The Anatomy of Disgust (Cambridge, MA: Harvard University Press, 1997), 54.

17. Erving Goffman, Stigma: Notes on the Management of Spoiled Identity (Englewood Cliffs, NJ: Prentice-Hall/London: Penguin, 1963). See also James Partridge, Changing Faces (London: Penguin, 1990). Partridge, the survivor of major burns in a car crash, notes how reading Goffman helped him to rationalize his own situation.

18. Julia Kristeva, Powers of Horror: an Essay on Abjection, tr. Leon S. Roudiez (New York: Columbia University Press, 1982), 53. Cf. Miller, Anatomy and Chap. 2, above, on the skin as a container.

19. Ipse turbabatur et erubescebat: the imperfect tense here indicates that Aldevrandus's distress was repeated or continuous: Chronica Fratris Salimbene Ordinis Minorum, 137.

20. E.g. William Ian Miller, Bloodtaking and Peacemaking: Feud, Law and Society in Early Saga Iceland (Chicago: Chicago University Press, 1990), 4-5, comments that "the saga writers of the thirteenth century anticipated the perspicacity of Erving Goffman" in their presentation and analysis of social interactions. Criticism: "Introduction: stigma reconsidered," in The Dilemma of Difference: a Multidisciplinary View of Stigma, ed. Stephen C. Ainlay, Gaylene Becker and Lerita M. Coleman (New York and London: Plenum Press, 1986), 1-13, at 8.

21. Goffman, Stigma, 12.

22. Colin Barnes, "Cabbage Syndrome": the Social Construction of Dependence (London/New York: The Falmer Press, 1990), 8-9.

23. Ibid., 18-19. Irina Metzler, A Social History of Disability in the Middle Ages: Cultural Considerations of Physical Impairment 
(London/New York: Routledge, 2013), 174, makes much the same point - provision for the medieval poor and sick did not encompass caring for the impaired if they were capable of working or begging.

24. Sally Crawford and Christina Lee, "Introduction," in Bodies of Knowledge: Cultural Interpretations of Illness and Medicine in Medieval Europe, ed. S. Crawford and C. Lee (Studies in Early Medicine 1/BAR International Series 2170, Oxford: Archaeopress, 2010), 2.

25. E. E. Jones, A. Farina, A. Hastorf, H. Markus, D. Miller and R. A. Scott, Social Stigma: the Psychology of Marked Relationships (New York: Freeman, 1984).

26. S. Shoham, The Mark of Cain: the Stigma Theory of Crime and Social Deviation (Jerusalem: Israel Universities Press, 1970), 1. Shoham thus summarily dismissed the physically-different from his subsequent discussion of stigma.

27. "...almost all persons who are in a position to pass will do so on some occasion by intent": Goffman, Stigma, 95; Sander Gilman, Making the Body Beautiful: a Cultural History of Aesthetic Surgery (Princeton/Oxford: Princeton University Press, 1999), 22.

28. See above, Chap. 3.

29. Luke Demaitre, pers. comm. July 2015, notes however that hats and hoods remain the exception in the sample of 25 or so pre1200 depictions of lepers he has found. He is currently preparing a study on medieval disease and disfigurement.

30. Cuius vulneris cicatrix quamdiu vixit apparmit: Chronicon Laetiense, c.12, ed. I. Heller, in MGH SS, XIV, ed. G. H. Pertz (Hannover: Hahn, 1883), 500.

31. Gerald of Wales, The Journey Through Wales, II.7, tr. L. Thorpe (London: Penguin, 1978), 190-1. Gerald adds that he himself had seen the same scar on Erchembald's son Stephen.

32. GT, V.48.

33. Cf. the case of Conrad vs. Henry discussed above.

34. The Chronicle of Theophanes Confessor: Byzantine and Near Eastern History, AD284-813, ed. and tr. C. Mango and R. Scott with the assistance of R. Greatrex (Oxford: Clarendon Press, 1997),

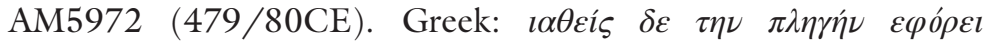

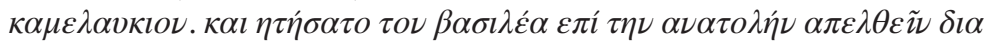

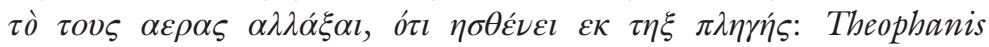


Chronographia, ed. C. de Boor, 2 vols (Hildesheim: Georg Olms, 1963), I, 128.

35. Thietmar, II.27: ...et fuit eiusdem mutilatio non ad dedecus, sed ad honorem magis; translated in Ottonian Germany, 112.

36. Levitical ban: Ruth Mellinkoff, Outcasts: Signs of Otherness in Northern European Art of the Late Middle Ages, 2 vols (Berkeley: University of California Press, 1993), I, 113-114; Irina Metzler, Disability in Medieval Europe (London: Routledge, 2006), 40.

37. Chronicle of Theophanes, AM5817 (324/5CE), 42; Theophanis, ed. De Boor, 27.

38. A knight "struck the pope's assailant more powerfully and fatally than Peter struck Malchus": Orderic, X.1 (V, 196-7).

39. Bretha Déin Chécht, clause 31, cited in Fergus Kelly, A Guide to Early Irish Law (Dublin: Dublin Institute of Advanced Studies, 1988), 132.

40. The Laws of Hywel Dda (The Book of Blegywryd), tr. Melville Richards (Liverpool: Liverpool University Press, 1954), 65.

41. Piers Mitchell, Medicine in the Crusades: Warfare, Wounds and the Medieval Surgeon (Cambridge: Cambridge University Press, 2004 ); id., Y. Nagar and R. Ellenbaum, "Weapon injuries in the twelfth century crusader garrison of Vadum Iacob castle, Galilee," International Journal of Osteoarchaeology, 16.2 (2006): $145-155$.

42. J. Prag and R. Neave, Making Faces: Using Forensic and Archaeological Evidence (London: British Museum Press, 1997). Images of the two effigies, kindly provided by Professor Prag and courtesy of the museum, can be viewed on my project blog: http://medievaldisfigurement.wordpress.com

43. Cf. Gerald of Wales' somewhat hazardous reports of Hugh, Earl of Shrewsbury ("the arrow struck his right eye and penetrated his brain"), who died, and Harold, king of the English, who allegedly survived ("wounded in many places, losing his left eye through an arrow which penetrated it but, although beaten, he escaped to these parts"): The Journey Through Wales, II.7 and 11, tr. L. Thorpe (London: Penguin, 1978), 188 and 198-9 respectively. And see below, Chap. 7.

44. Liber ad Honorem Augusti di Pietro da Eboli, XV, ed. G. B. Siragusa (Rome: Istituto Storico Italiano, 1906), 34. On the limited possibilities of surgery in early medieval Italy, see Clare Pilsworth, 
Healthcare in Early Medieval Northern Italy (Turnhout: Brepols, 2014), 104-111.

45. The present study went to press just as Wounds and Wound Repair, ed. DeVries and Tracy, was published. The collected essays in this volume represent a significant leap forward in the study of wound care, including that of injuries received on the battlefield.

46. Above, Chap. 3. Agnellus is our only source for this: Joaquín Martinez Pizarro, Writing Ravenna: The Liber Pontificalis of Andrea Agnellus (Ann Arbor: University of Michigan Press, 1995), 183.

47. Pers. comm. Dr Mark Bradley, 4 March 2014. Compare the gold nose commissioned by Emperor Otto III for the slightly crumbling corpse of Charlemagne when the latter's tomb was opened in the year 1000: Chronicon Novaliciense, III.32, ed. G. H. Pertz, MGH SS rer. Germ., XXI (Hannover: Hahn, 1846), 55. This, too, has misled subsequent scholars into thinking that it was Otto who wore it: Julie Singer, Blindness and Therapy in Late Medieval French and Italian Poetry (Woodbridge: Boydell and Brewer, 2011), 149. See also Antony Eastmond, "Between icon and idol: the uncertainty of imperial images," in Icon and Word: the Power of Images in Byzantium, ed. A. Eastmond and L. James (Aldershot: Ashgate, 2005), 73-85.

48. Metzler, Disability in Medieval Europe, 31.

49. On the power of gossip and reputation, Ronald S. Burt, Brokerage and Closure: an Introduction to Social Capital (Oxford: Oxford University Press, 2005), and on words as violent acts, William Ian Miller, Humiliation and Other Essays on Honor, Social Discomfort and Violence (Ithaca/London: Cornell University Press, 1998), 83. On the middle ages specifically: Susan E. Phillips, Transforming Talk: the Problem with Gossip in Late Medieval England (University Park: Penn State University Press, 2007); Fama: the Politics of Talk and Reputation in Medieval Europe, ed. Thelma Fenster and Daniel Lord Smail (Ithaca, NY: Cornell University Press, 2003); Chris Wickham, "Gossip and resistance among the medieval peasantry," Past and Present, 160 (1998): 3-24.

50. Above, Chap. 1.

51. As modern examples illustrate, however, the level of stigmatization experienced by an individual might increase sharply if they moved to an area where the circumstances of their disfigurement were unknown: Gaylene Becker and Regina Arnold, "Stigma as a social 
and cultural construct," in Dilemma of Difference, ed. Ainlay, Becker and Coleman, 39-57, at 49, highlight the case of a disfigured World War II freedom fighter's experiences when moving from Europe to the United States.

52. See the discussion in Stephen Wilson, The Means of Naming: a Social History (London: UCL Press, 1998), especially 118-123 and 280-289. Nicknames referring to appearance are noted by Bragg, "Disfigurement, disability and dis-integration," and by Metzler, A Social History of Disability, 37; Patricia Skinner, "And her name was?' Gender and naming in medieval southern Italy," Medieval Prosopography, 20 (1999), 23-49. Gerald of Wales, Journey through Wales, II.8, mentions Iorwerth Drwyndwn "which is the Welsh for Fat-Nosed"; in fact the term suggests a nose that is broken, and thus appears wider.

53. On this issue: Skinner, "Visible prowess?"

54. Mechthild Gretsch, "The language of the 'Fonthill letter'," AngloSaxon England, 23 (1994): 57-102, at 99: Đa he fleah, da torypte hine an breber ofer dat nebb; da he etsacan wolde, da sade him mon dat to tacne. English translation cited from ibid., 101. I am grateful to Charles Insley for introducing me to this fascinating text.

55. GT, VIII.29 (c. 585 CE) (393) and X.18 (509: "ad ridiculum laxaverunt").

56. Wheatley, Stumbling Blocks, 21.

57. Mark C. Stafford and Richard R. Scott, "Stigma, deviance and social control: some conceptual issues," in Dilemma of Difference, ed. Ainlay, Becker and Coleman, 77-91, at 86. Stafford and Scott comment that at the time of writing this dynamic of power had not been fully explored within stigma studies.

58. Umberto Eco, On Beauty, tr. A. McEwan (London: Secker and Warburg, 2004), 8; U. Eco, On Ugliness (London: Harvill Secker, 2007), 19.

59. Alexiad, I.x. All English quotations from The Alexiad of Anna Comnena, tr. E. R. A. Sewter (London: Penguin, 1969).

60. Alexiad, III.iii.

61. For the most part, however, according to Eco, "medieval man did not apply a mathematics of proportions to the appraisal or reproduction of the human body": On Beauty, 77.

62. Self and Society, I.2, 38 (mother) and 40 (quote).

63. For a full discussion see Skinner, "Gendered nose and its lack." 
64. In Codex 1 of The Assizes of the Lusignan Kingdom of Cyprus, tr. Nicholas Coureas (Nicosia: Cyprus Research Centre, 2002), corporal punishments include cutting the tongue of a slave who dares to summon his master to court (I.16), or someone who wrongly challenges a judgment in court and cannot pay compensation (I.253); loss of a hand for an assault leaving an open wound, including to the head (I.118 and 254) and for forging documents (I.273); loss of the penis for ravishing a virgin if no settlement can be reached (I.127); and branding on the palms of the hands of a person offering testimony for gain (I.131). In addition, a first-time thief could be beaten, paraded publicly and branded (the clause does not specify where: I.281). Specific mutilation of the face, however, does not figure in this collection.

65. The relevant report is reproduced and discussed in Philip Pulsiano, "Blessed bodies: the vitae of Anglo-Saxon female saints," Parergon 16.2 (1999): 1-42.

66. Acta Sanctorum, vol. XI, 20 April, Vita Ven. Oda Praemonstratensis; Acta Sanctorum, vol III, 28 January, B. Margaritae Hungariae Virginis; Acta Sanctorum, vol. VI, 22 February, De B. Margarita Poenit. Tertii Ord. S. Francisci Cortonae in Etruria respectively.

67. For a fuller discussion of these three saints, see Patricia Skinner, "Marking the face, curing the soul? Reading the disfigurement of women in the later middle ages," in Medicine, Religion and Gender in Medieval Culture, ed. Naoë Kukita Yoshikawa (Woodbridge: Boydell, 2015), 287-318.

68. The Destruction of Da Derga's Hostel, in Early Irish Myths and Sagas, tr. Jeffrey Gantz (London: Penguin, 1981), 71.

69. The tale is discussed in Tory Vandeventer Pearman, Women and Disability in Medieval Literature (New York: Palgrave Macmillan, 2011), 74-83.

70. Self and Society, III.8 (176).

71. Gilman, Making the Body Beautiful, xix.

72. Annales Bertiniani s.a. 864, ed. G. Waitz, MGH SS rer. Germ., V (Hannover: Hahn, 1883), 67: Carolus iuvenis... noctu rediens de venatione in silva Cotia iocari cum aliis iuvenibus et coaevis suis putans, operante diabolo ab Albuino iuvene in capite spatha percutitur pene usque ad cerebrum; quae plaga a timpore sinistro usque ad malam dextrae maxillae pervenit. English translation: The Annals 
of St Bertin: Ninth-Century Histories vol I, tr. J. L. Nelson (Manchester: Manchester University Press, 1991), 111-112.

73. Janet L. Nelson, pers. comm., comments that Charles seems not to have done anything as sub-king thereafter, implying that he was effectively incapacitated.

74. Ex Adonis Archiepiscopi Viennensis Chronico, ed. I. de Arx, MGH SS, II (Hannover: Hahn, 1829), 323. "Dehonestatus" implies loss of dignity and looks, since the adjective honestus could be used to describe a handsome man as well as an honest or honorable one.

75. Reginonis Abbatis Prumiensis Chronicon, s.a. 870, ed. F. Kurze, MGH SS rer. Germ., L (Hannover: Hahn, 1890), 101.

76. Thietmar, IV.21 and see above, Chap. 2.

77. Liber ad Honorem Augusti, ed. Siragusa, XV, 34: Illudensque viris ars quibus arcus erat... Lapsaque per medias arsit arundo genas. Translation from The Book in Honour of the Emperor, tr. G. A. Loud, I. Moxon and P. Oldfield (2006), online at http://www. leeds.ac.uk/arts/info/125040/medieval_studies_research_ group $/ 1102 /$ medieval_history_texts_in_translation [accessed 15 May 2015].

78. On this topic (for a later period) see the collected essays in The Stranger in Medieval Society, ed. F. R. P. Akehurst and Stephanie Cain Van d'Elden (Minneapolis: Minnesota University Press, 1997).

79. Chronicle of Theophanes, AM6081 (588/9CE), 389; Theophanis, ed. de Boor, 266.

80. Kelly, Guide, 8 (face price) and 19 (kingship).

81. II Cnut, in English Historical Documents, I, tr. D. Whitelock (2nd edition, London: Routledge, 1979), 458-9.

82. Slave: II Cnut, 32, in ibid., 459.

83. Gregory: above, Chap. 3, note 33; Orderic: above, Chap. 3, note 71.

84. See above, Introduction, discussion of Ezzelino da Romano. The use of extreme violence towards corpses is another common marker of the evil of the perpetrators, as for example in Walter's extended description of the killing and mutilation of Charles the Good of Flanders in 1127. Having killed the count, the murderers continued to wound his head and cut off his right arm: Walteri Vita Karoli Comitis Flandriae, in MGH SS, XII, ed. G. H. Pertz (Hannover: Hahn, 1856), 549. 
85. Amatus of Montecassino, The History of the Normans, tr. Prescott N. Dunbar with introduction by G. A. Loud (Woodbridge: Boydell, 2004), VIII.2, 188, and see also VIII.3 (189-90) and VIII.11 (192).

86. Bartholomaei Scribae Annales s.a. 1245, in MGH SS, XVIII, ed. G. H. Pertz (Hannover: Hahn, 1863), 219.

87. Gaylene Becker and Regina Arnold, "Stigma as a social and cultural construct," in Dilemma of Difference, ed. Ainlay, Becker and Coleman, 39-57, at 46, also make the point that stigma can be mitigated by social class - the individual can literally rise above her or his condition.

88. faciem eius horrendi militis tactu lesam perspexi: Orderic, VIII.17 (IV, 248-9).

89. Thietmar, II.40.

Open Access This chapter is distributed under the terms of the Creative Commons Attribution 4.0 International License (http://creativecommons.org/licenses/by/4.0/), which permits use, duplication, adaptation, distribution and reproduction in any medium or format, as long as you give appropriate credit to the original author(s) and the source, provide a link to the Creative Commons license and indicate if changes were made.

The images or other third party material in this book are included in the work's Creative Commons license, unless indicated otherwise in the credit line; if such material is not included in the work's Creative Commons license and the respective action is not permitted by statutory regulation, users will need to obtain permission from the license holder to duplicate, adapt or reproduce the material.

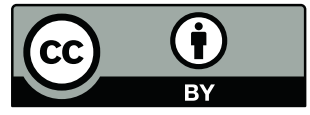

